\title{
Anti-inflammatory, analgesic and acute toxicity effects of fermented soybean
}

\author{
Hamidah Mohd Yusof ${ }^{1}$, Norlaily Mohd Ali', Swee Keong Yeap², Wan Yong Ho ${ }^{3}$, Boon Kee Beh ${ }^{4}$, Soo Peng Koh', \\ Kamariah Long ${ }^{5}$ and Noorjahan Banu Alitheen ${ }^{1,4^{*}}$ (D)
}

\begin{abstract}
Background: Tempeh is a widely known fermented soybean that contains elevated level of bioactive contents. Our previous study has shown that anaerobic fermented Nutrient Enriched Soybean Tempeh (NESTE) with increase amino acid and antioxidant levels possessed better hepatoprotective effect than raw soybean.

Methods: In this study, the anti-inflammatory effect of the NESTE aqueous extract and raw soybean aqueous extract (SBE) were evaluated by quantifying the inhibition of IL-1 $\beta$, TNF-a and nitric oxide (NO) secretion in LPS treated RAW 264.7 cell in vitro. On the other hand, in vivo oral acute toxicity effect of the extract was tested on mice at the dose of $5000 \mathrm{mg} / \mathrm{kg}$ body weight. In vivo oral analgesic effect of both aqueous extracts at 200 and $1000 \mathrm{mg} / \mathrm{kg}$ body weight was evaluated by the hot plate test.

Results: In the in vitro anti-inflammatory study, $5 \mathrm{mg} / \mathrm{mL}$ NESTE was able to inhibit $25.50 \pm 2.20 \%, 35.88 \pm 3.20 \%$ and $28.50 \pm 3.50 \%$ of NO, IL-1 $\beta$ and TNF-a production in LPS treated RAW 264.7 cells without inducing cytotoxic effect on the cells. However, this effect was lower than $4 \mu \mathrm{g} / \mathrm{mL}$ of curcumin, which inhibited NO, IL-1 $\beta$ and TNF-a production by $89.50 \pm 5.00 \%, 78.80 \pm 6.20 \%$ and $87.30 \pm 4.00 \%$, respectively. In addition, 1.5 to 2.5 -fold increase of latency period up to $120 \mathrm{~min}$ for mice in the hot plate test was achieved by $1000 \mathrm{mg} / \mathrm{kg} \mathrm{NESTE}$. The analgesic effect of NESTE was better than $400 \mathrm{mg} / \mathrm{kg}$ of acetyl salicylic acid, which only increased $\sim 1.7$-fold of latency period up to $90 \mathrm{~min}$. Moreover, NESTE did not show acute toxicity (no LD $\mathrm{L}_{50}$ ) up to $5000 \mathrm{mg} / \mathrm{kg}$ body weight.
\end{abstract}

Conclusion: NESTE is a nutritious food ingredient with potential anti-inflammatory and analgesic effects.

Keywords: Fermented, Soybean, Anti-inflammation

\section{Background}

Inflammation is one of the naturally occurring mechanisms in the body that involves in protection against tissue injury due to physical trauma, noxious chemicals and microbial agents [1]. This response plays a vital role in the process of eliminating the invading organisms, removing the irritants and generating chemical mediators for repair of injured tissue and migrating cells $[1,2]$. Macrophage is one of the immune cells that generate the chemical mediators such as reactive oxygen species (ROS) and reactive nitrogen species (RNS) when the inflammatory signalling response is activated by immune-stimulants, including bacterial endotoxin

\footnotetext{
* Correspondence: noorjahan@upm.edu.my

'Department of Cell and Molecular Biology, Faculty of Biotechnology and Biomolecular Science, Universiti Putra Malaysia, 43400 Serdang, Selangor, Malaysia

${ }^{4}$ Institute of Bioscience, Universiti Putra Malaysia, Serdang, Selangor, Malaysia Full list of author information is available at the end of the article
}

lipopolysaccharide (LPS) and interferon-gamma (IFN- $\gamma$ ) [3]. Nevertheless, over-expression of these mediators can subsequently induce inflammatory diseases such as rheumatoid arthritis, atherosclerosis, chronic hepatitis and pulmonary fibrosis $[4,5]$. Prevention of the development of chronic inflammatory diseases could be inhibited via suppression of the over-expressed mediators [5]. Common treatment used to treat inflammatory diseases is via non-steroidal anti-inflammatory drugs (NSAIDs), which has reported to exhibit various adverse effects such as gastric pain, intestinal injuries and complication that involves the whole parts of the gastrointestinal tract [6-8]. Hence, search of novel anti-inflammatory agents with less or no toxic effect from natural sources is of interest.

Active metabolites such as proteins, phenolic compounds and antioxidants that were found in the soybean-based 
foods were reported to exhibit the anti-inflammatory effects [9]. One of the soybean-based foods that are largely consumed and incorporated in the daily diet in certain regions of Asia is fermented soybean. The fermentation process was able to generate an increased the level of soluble bioactive substances due to the microbial activities in soybean [10]. The benefits of antioxidants and amino acids, which are found to be substantially higher in fermented soybeans, are usually linked to the anti-inflammatory activity [11]. One of the most commonly consumed fermented soybeans around South East Asia is tempeh which contained significant level of antioxidants and amino acids [12, 13], which may subsequently contribute to the anti-inflammatory effect. Thus, the objectives of this study were to compare anti-inflammatory effect between Nutrient Enriched Soybean Tempeh (NESTE) aqueous extract and Soybean aqueous extract $(\mathrm{SBE})$ through in vitro regulation of nitric oxide (NO) production in LPS-induced mice macrophage cells (RAW 264.7) and in vivo arachidonic acid induced mice ear edema as well as analgesic effect via in vivo hot plate test. Additionally, the acute toxicity of NESTE was also determined.

\section{Methods}

\section{Chemicals and reagents}

3-(4,5-dimethylthiazol-2-yl)-2,5-diphenyltetrazolium bromide (MTT), acetyl salicylic acid, dexamethasone, lipopolysaccharide (LPS), curcumin and Dulbecco's Modified Eagle Medium (DMEM) were purchased from Sigma (USA), foetal bovine serum (FBS) from PAA (Austria), dimethyl sulfoxide (DMSO) from Fisher Scientific (UK) and arachidonic acid from Merck (USA).

\section{Animals}

Five to six weeks old of male $(n=51)$ and female $(n=51)$ $\mathrm{Balb} / \mathrm{c}$ mice with the average weight of 15 to $23 \mathrm{~g}$ were purchased from animal house, Faculty of Veterinary, Universiti Putra Malaysia. Mice were kept in plastic cage (3 or 4 mice per cage, autoclave sawdust) under controlled condition with a cycle of $12 \mathrm{~h}$ light and $12 \mathrm{~h}$ dark at $25^{\circ} \mathrm{C}$ and were acclimatized for at least 1 week and supplied with standard diet pellet and water ad libitum. The experiments were approved by Institutional Animal Care and Use (IACUC) Committee, Universiti Putra Malaysia (UPM) (Ref: UPM/ FPV/ PS/ 3.2.1.551/AUP-R2) and compliance to the guidelines of the IACUC, UPM.

\section{Preparation of NESTE and SBE}

Soybeans were obtained from the local market at Selangor, Malaysia, which was originated from Canada. Soybean samples was identified by the Science Officer Mr. Shaiful Sharifudin from MARDI and the voucher specimen (voucher no: MARBI 002) has been deposited at Biotechnology Research Center, MARDI. The starter culture of Rhizopus
5351 strain was obtained from the Bioprocess Department of Biotechnology Research Centre, Malaysian Agricultural Research and Development Institute (MARDI) and maintained at $4{ }^{\circ} \mathrm{C}$ for its growth. The preparation and extraction of raw soybean (SBE) and Nutrient-enriched soybean tempeh (NESTE) were carried out according to our previously published method [14]. Our previous study has reported that lyophilized NESTE contained $0.338 \pm 0.025 \mathrm{~g} / 100 \mathrm{~g}$ DW (dried weight) of gammaaminobutyric acid (GABA), $2.176 \pm 0.006 \mathrm{~g} / 100 \mathrm{~g}$ DW of total free amino acids, $42.64 \pm 1.59 \mu \mathrm{g} / \mathrm{g}$ extract of soluble phenolic acids and $22.56 \pm 0.31 \mathrm{mg}$ gallic acid equivalent (GAE)/g extract of total phenolic acids [14]. Total free amino acids and GABA were quantified using Waters Acquity Ultra Performance Liquid Chromatography (UPLC) by Acquity UPLC AccQ Taq Ultra Column and UV-photodiode array (PDA) detector set at $260 \mathrm{~nm}$. On the other hand, soluble phenolic acids content was quantified by high-performance liquid chromatography (HPLC) using Chromolith Performance RP-18e column. In addition, total phenolic content was quantified by Folin-Ciocalteu reagent [14].

\section{In vitro anti-inflammatory activity}

Mouse macrophage cell line (RAW264.7) was obtained from the American Type Culture Collection (ATCC) and maintained in Dulbecco's Modified Eagle Medium (DMEM) supplemented with $2 \mathrm{mM}$ glutamine, antibiotics (100 units $/ \mathrm{mL}$ penicillin A and 100 units/mL streptomycin) and 10\% heatinactivated foetal bovine serum (FBS). The cells were then incubated in $5 \% \mathrm{CO}_{2}$ at $37^{\circ} \mathrm{C}$.

The MTT assay was conducted according to Mosmann [15]. Briefly, 2 X $10^{5}$ cells/ mL of RAW264.7 cell was seeded in 96-well plate and allowed to attach overnight. Then, the cell was treated with various concentration of NESTE or SBE $(0.63,1.25,2.50$ and $5 \mathrm{mg} / \mathrm{mL})$ for $24 \mathrm{~h}$. After the incubation time, $20 \mu \mathrm{L}$ of $5 \mathrm{mg} / \mathrm{mL}$ MTT was added to each well and $170 \mu \mathrm{L}$ of media was aspirated after $3 \mathrm{~h}$ of incubation in the dark. Then, $100 \mu \mathrm{L}$ of DMSO was added to each well to dissolve the crystal formazan and the optical density was measured at $570 \mathrm{~nm}$ by ELISA plate reader (Bio-Tek Instruments, USA).

The in vitro anti-inflammatory effect of SBE and NESTE were quantified by comparing the inhibition of extracellular secretion of nitric oxide (NO), IL-1 $\beta$ and TNF- $\alpha$ of LPS activated RAW264.7 cells after treated with 2.5 and $5 \mathrm{mg} / \mathrm{mL}$ of SBE or NESTE. Briefly, RAW264.7 cells were activated with $1 \mu \mathrm{g} / \mathrm{mL}$ of LPS with or without the treatment of 2.5 and $5.0 \mathrm{mg} / \mathrm{mL}$ of SBE or NESTE. Curcumin $(4 \mu \mathrm{g} / \mathrm{mL})$ was used as positive anti-inflammatory compound control. After $24 \mathrm{~h}$ of incubation, of culture supernatant was collected for NO, IL-1 $\beta$ and TNF- $\alpha$ quantification. NO quantification was carried out using calorimetric Griess reaction kit (Molecular Probes, Inc., USA) according to Huang et al. 
[16], where $150 \mu \mathrm{L}$ of supernatant was added with $20 \mu \mathrm{L}$ of Griess Reagent and $130 \mu \mathrm{l}$ of deionized water. Then, the reaction mixture was incubated for $30 \mathrm{~min}$ and the absorbance was measured at $548 \mathrm{~nm}$ wavelength using Bio-Tek ELISA (USA) plate reader. Standard calibration curve of sodium nitrite ranging from 1 to $100 \mu \mathrm{M}$ was prepared concurrently and expressed as nitrite concentration $(\mu \mathrm{M})$. The data was presented as percentage of nitric oxide inhibition. On the other hand, IL- $1 \beta$ and TNF- $\alpha$ were quantified using ELISA kit (BioLegend, USA) according to the manufacturer's instructions. Each sample was assayed in triplicates.

\section{In vivo acute toxicity activity}

Acute toxicity of SBE and NESTE was evaluated according to the OECD guideline [17]. Male and female ICR mice were divided into three groups where each group represents five males and five females in separate cages. The first group received distilled water (normal control), the second group received single oral dose $5000 \mathrm{mg} / \mathrm{kg}$ body weight of SBE while for the third group received single oral dose $5000 \mathrm{mg} / \mathrm{kg}$ body weight of NESTE (100 $\mu \mathrm{L}$, dissolved in distilled water). After administration of the extracts (in the morning), mice were observed for abnormality and mortality for subsequent 1 , $2,4,6,24 \mathrm{~h}$ and up to days 14 . At the end of the assessment, all the survived mice were anesthetized with $2 \%$ isoflurance (Merck, USA), sacrificed by cervical dislocation and the internal organs including liver, kidney and spleen were dissected, weight and fix for histopathology study using Hematoxylin and Eosin (H and E) staining [18]. In addition, the weight of the three organs (liver, kidney and spleen) was presented as organ index and measured as per below formula;

Organ index $=$ weight of mice organ $(\mathrm{g}) /$ body weight of mice $(\mathrm{g})$ X 100

\section{Mice paw analgesia test}

Hot plate method was used to induce pain for the mice paw according to Tapondjou et al. [19]. Hot plate was employed to introduce the heat to the mice and the response latencies were measured based on the time taken for the mice to start licking, shaking the hind paw or jumping. Briefly, mice were fasted for $24 \mathrm{~h}$ prior to experiment and randomly separated into 6 groups $(n=6,3$ male and 3 female). All mice were pre-treated orally (p.o.) with $100 \mu \mathrm{L}$ of solution 30 min prior to placement on hot plate according to the following treatment. Group 1 represented mice fed with distilled water (negative control), group 2 represented mice treated with acetyl salicylic acid $(400 \mathrm{mg} / \mathrm{kg}$, dissolved in carboxymethylcellulose), group 3 and 4 represented mice treated with $200 \mathrm{mg} / \mathrm{kg}$ and $1000 \mathrm{mg} / \mathrm{kg}$ of SBE (dissolved in distilled water), respectively and group 5 and 6 represented mice treated with $200 \mathrm{mg} / \mathrm{kg}$ and $1000 \mathrm{mg} / \mathrm{kg}$ of NESTE (dissolved in distilled water), respectively. Thirty minutes after treatments, each mouse was put onto hot plate with a temperature of $55^{\circ} \mathrm{C}$ individually and the response was monitored based on the mice reaction of paw licking or jumping. The latency until mice react by paw licking or jumping was recorded. This step was repeated at 60, 90 and $120 \mathrm{~min}$ after treatment to monitor the prolong analgesic effect of the treatment. Baseline (presented as $0 \mathrm{~min}$ ) of each groups of mice was obtained by monitoring the reaction of mice on hot plate before the treatment. Data was expressed as the reduction number of response latency between control and extracts-treated mice.

\section{Statistical analysis}

All the results were analysed using Statistical Package for the Social Sciences (SPSS version 18) (SPSS Inc., USA) software and expressed as means \pm standard error mean (S.E.M). One-way analysis of variance (ANOVA) with Duncan post-hoc was used to obtain the mean differences and $p$ value with less than $0.05(p<0.05)$ was considered as significant.

\section{Results \\ Viability of RAW264.7 cells by MTT assay}

Figure 1 illustrated the effect of NESTE and SBE on viability of RAW 264.7 cell. Both NESTE and SBE did not induce cytotoxic effect toward RAW 264.7 cell even at the highest concentration of $5 \mathrm{mg} / \mathrm{mL}$. Furthermore, both extracts have no significant differences with the control group (untreated cells). This result indicates that both NESTE and SBE did not influence the viability of RAW 264.7 cell.

\section{LPS-induced NO production in RAW 264.7 cells}

The effect of NESTE and SBE on LPS-induced NO, IL-1 $\beta$ and TNF- $\alpha$ production in RAW 264.7 cell was summarized in Fig. 2. Both concentrations of NESTE and SBE inhibited secretion of the NO, IL- $1 \beta$ and TNF- $\alpha$ by the LPS activated RAW 264.7 after $24 \mathrm{~h}$ of incubation. Furthermore, $5 \mathrm{mg} / \mathrm{mL}$ of NESTE showed the highest inhibitory effect, ie $25.50 \pm 2.20 \%, 35.88 \pm 3.20 \%$ and $28.50 \pm 3.50 \%$, respectively on NO, IL- $1 \beta$ and TNF- $\alpha$ production by LPS treated RAW 264.7 cells as compared to $5 \mathrm{mg} / \mathrm{mL}$ of SBE $(18.50 \pm 2.0 \%, 27.80 \pm 3.40 \%$ and $20.00 \pm$ $2.30 \%$, respectively), which indicated that fermentation process has significantly improved the in vitro antiinflammatory effect of soybean. However, this effect is lower comparing to the inhibition of the reference compound $4 \mu \mathrm{g} / \mathrm{mL}$ of curcumin, which inhibited the NO, IL$1 \beta$ and TNF- $\alpha$ production by $89.50 \pm 5.00 \%, 78.80 \pm 6.20 \%$ and $87.30 \pm 4.00 \%$, respectively. 


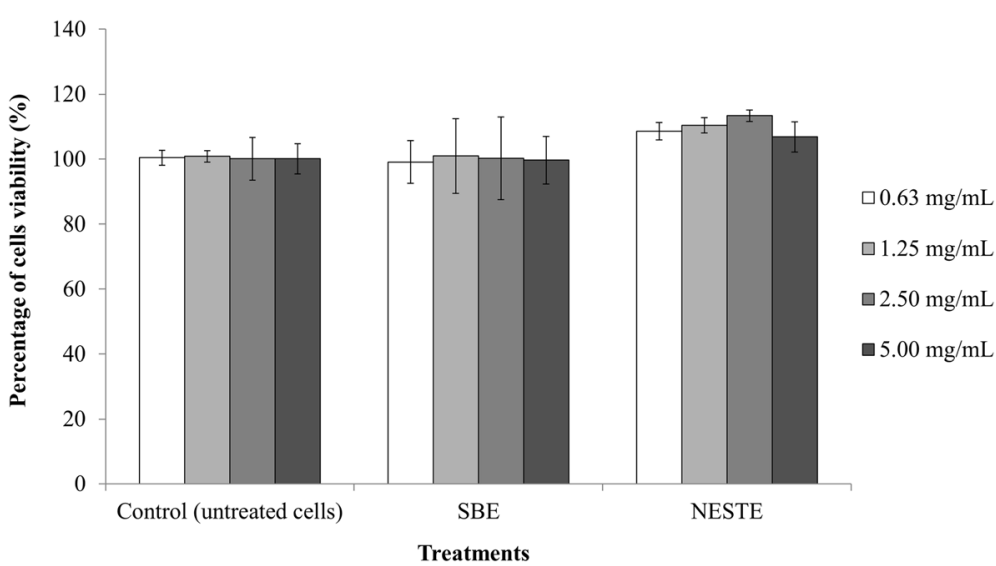

Fig. 1 Percentage of RAW264.7 cells viability by MTT assay after treated with various concentration of NESTE and SBE for $24 \mathrm{~h}$. Note: All of the values are expressed as means \pm S.E.M. from three separate experiments

\section{In vivo acute toxicity of NESTE and SBE}

Single administration of $5000 \mathrm{mg} / \mathrm{kg}$ of NESTE and SBE was used in the acute toxicity study (OECD, 2001). All mice $(n=30)$ survived up to day-14 post-treated with SBE $(n=$ $10)$ and NESTE $(n=10)$. Furthermore, no significant difference was observed in body weight, organ weight (spleen, liver and kidney) and organ histopathology (spleen, liver and kidney) (Data not shown) among the groups.
In vivo analgesic effect of NESTE and SBE on mice by hot plate test

Analgesic effect of NESTE and SBE tested by the hot plate method in mice was summarized in Fig. 3. Mice treated with $400 \mathrm{mg} / \mathrm{kg}$ acetyl salicylic acid showed a significant analgesic effect showing by 1.7 -fold increase of latency period than the untreated mice. However, this effect was only observed until $90 \mathrm{~min}$. Nevertheless, 1.5
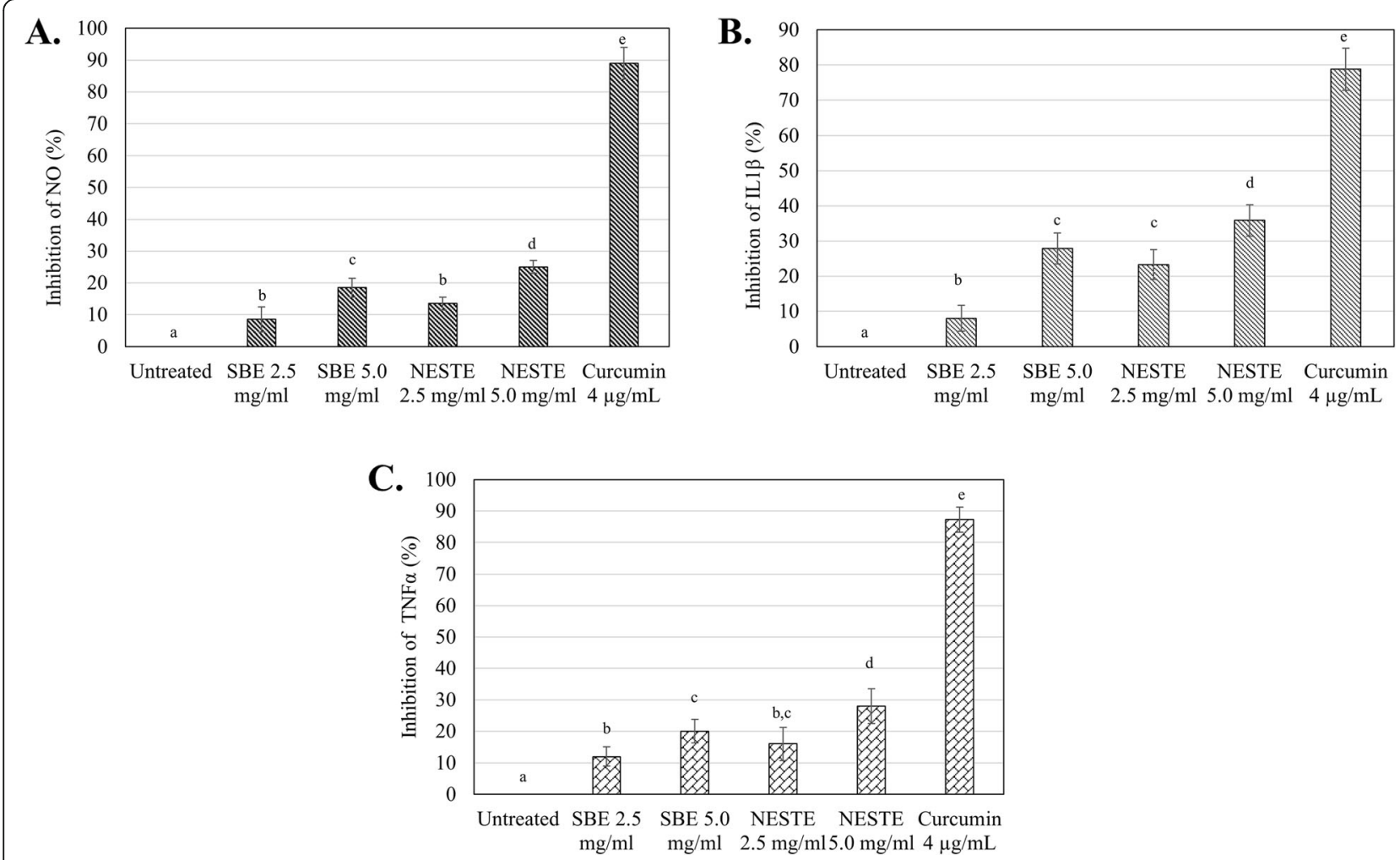

Fig. 2 The effect of SBE and NESTE treatments towards the percentage of a nitric oxide; $\mathbf{b} \| \mathrm{L} 1 \beta$; $\mathbf{c}$ TNFa inhibition on LPS-induced RAW264.7 cells. Note: All of the values are expressed as means \pm S.E.M. from three separate experiments, 'a' value has a significance differences $(p<0.05)$ with 'b' value 


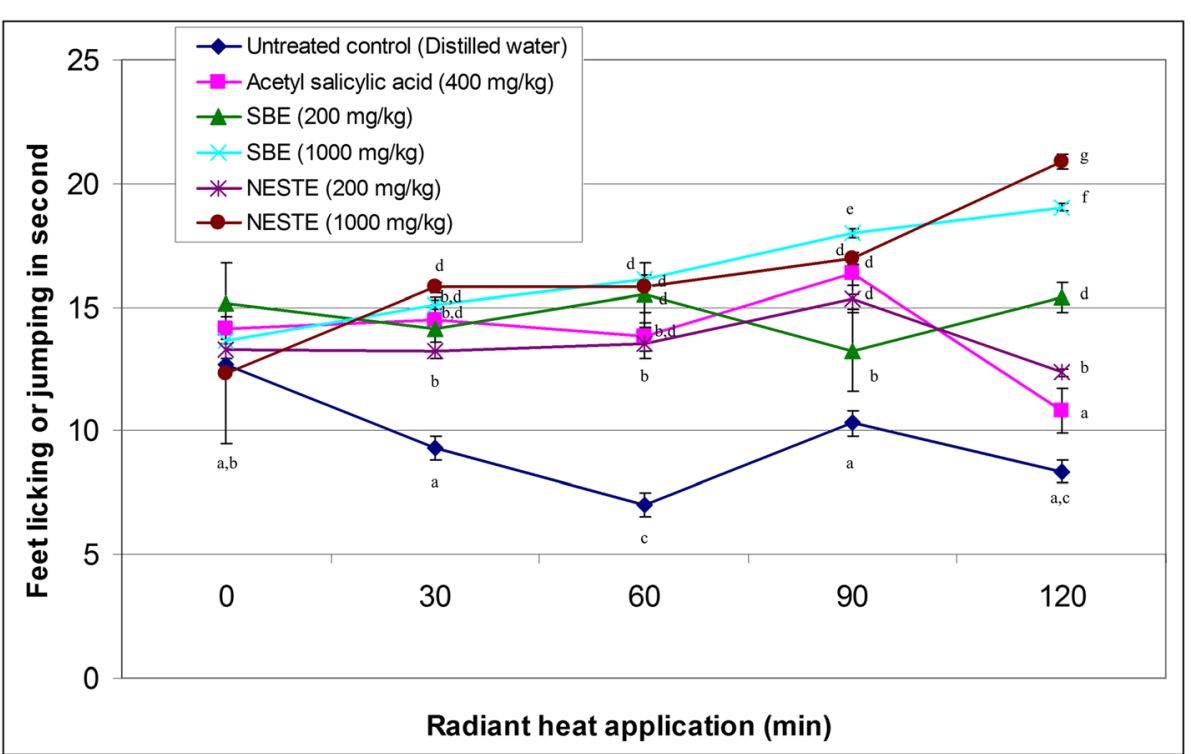

Fig. 3 Analgesic activity of NESTE and SBE by hot plate method on mice. Note: The data represents as mean of licking/jumping for every $40 \mathrm{~s} \pm$ S.E.M from six mice, Acetyl salicylic acid was used as reference substances

to 2.5-fold increase of latency period that last until 120 min of analgesic effect was shown in $1000 \mathrm{mg} / \mathrm{kg}$ NESTE treated mice where the effect demonstrated longer response for mice to resist the heat effect from hot plate up to $120 \mathrm{~min}$.

\section{Discussion}

Bacterial endotoxin lipopolysaccharides (LPS) activated mice macrophage cell lines (RAW 264.7) was commonly used as a model to investigate in vitro anti-inflammatory activity (Szliszka et al. 2011). Macrophage cells are generally known to have various pivotal roles in inflammatory diseases including discharging of inflammatory factors such as reactive oxygen species (ROS), reactive nitrogen species (RNS) and cytokines under the stimulation of immunostimulator such as bacterial endotoxin lipopolysaccharides (LPS) and interferon-gamma (IFN- $\gamma$ ) $[3,20]$. The uncontrolled responses of these inflammatory factors could contribute to chronic inflammatory diseases including cellular dysfunction and tissues damage [5]. The significant bioactivity level of NESTE was proven to suppress the overexpression in the inflammatory activities. Furthermore, NESTE has no toxicity effect to the viability of RAW 264.7 cell line, which indicated that NESTE would not interferes the RAW 264.7 cell activity, as it simultaneously slows down the uncontrolled inflammatory responses. In the inflammatory reaction, macrophage generates nitric oxide (NO) which is usually detected as iNOS (inducible nitric oxide synthase) [21]. Generally, several functions in physiological and pathological activities have been reported in NO. However, chronic inflammatory diseases as well as autoimmune diseases could induce by an increase level of NO $[4,5]$. NO and proinflammatory cytokines including IL-1 $\beta$ and TNF- $\alpha$ were involved in LPS induced inflammation of macrophages, which mimic the clinical sepsis-induced inflammatory responses. Suppression of NO production was reported with inhibition of LPSinduced IL-1 $\beta$ and TNF- $\alpha$ proinflammatory cytokines production [22]. The significant reduction of NO level was observed in the LPS induced RAW 264.7 cells treated with NESTE and this suggested that the effect of NESTE was comparable to the effect of fermented soymilk in the previous study, which had been revealed to inhibit the production of $\mathrm{NO}$ that subsequently suppressed the IL-1 $\beta$ and TNF- $\alpha$ proinflammatory cytokines production in LPS induced macrophage [11, 22]. Moreover, the hot plate test also demonstrated that NESTE treatment was the most efficient to induce the analgesic effect towards mice. These results suggested that NESTE potentially possess better in vitro anti-inflammatory and in vivo anti-analgesic effects than SBE. These results are similar with our previous report where NESTE was able to reduce NO level in the liver of mice treated with ethanol. This anti-inflammatory effect was correlated with the enhanced antioxidant level of the soybean through fermentation [23].

The prevalence of toxicity in fermented foods always correlate to the contaminants from microbial foodborne intoxication which was previously reported in majority of all types of fermented foods including cheese, sausages, fermented fish and fermented cereals [24]. Evaluation of the acute toxicity test in NESTE treatment group has shown that it has no acute toxicity and $\mathrm{LD}_{50}$ 
up to day 14. Furthermore, result of mice body weight gain, organs indices and histopathological examination in NESTE treatment group were shown to be comparable to the normal control group. These results were agreeable with the previous study, which revealed that tempeh is free from the hazard of foodborne intoxication [24].

Tempeh is a common fermented food in Asia including Indonesia, Malaysia, Thailand and Japan. Previous study has shown that daily recommended dosage was $250 \mathrm{~g}$ per person. In this study, the dose per $60 \mathrm{~kg}$ for human are $0.976 \mathrm{~g} / 60 \mathrm{~kg}$ and $4.878 \mathrm{~g} / 60 \mathrm{~kg}$ (based on the conversion of body surface area of mice to human) [25], respectively. As the extraction recovery for the tempeh extract was $25 \%$ [14], the amount of tempeh to achieve the tested dosage are $3.904 \mathrm{~g} / 60 \mathrm{~kg}$ and $19.512 / 60 \mathrm{~kg}$ per person. This concentration is below the recommended daily dosage proposed by Nakajima et al. [26]. Better effect of NESTE maybe contributed by higher number of bioactive compounds detected in NESTE compared to SBE such as GABA by 328 -fold, free amino acid by $32-$ fold, essential amino acid by 157 -fold and TSPC by $2.3-$ fold. Furthermore, the overall flavonoids and antioxidant activities tested by total phenolic content, DPPH and FRAP assays exhibited significant increment [14]. Thus, we presumed that the augmented amount of these compounds may directly or indirectly contribute to the anti-inflammatory and analgesic effects. The findings were further supported by similar publications by other researcher on anti-inflammatory effect exhibited by such bioactive compounds, flavonoids [27], GABA [28], amino acids [29] and antioxidant activity [30]. Similarly, analgesic effects were shown in various other researches [31-33]. In addition, Mothana et al. [34] have claimed that antioxidant activity of plant flavonoids and phenolic acids is able to scavenge the reactive oxygen species (ROS), which are mainly involved in inflammation pathology [34].

\section{Conclusion}

Increment of several bioactive compounds such as antioxidants, GABA, amino acids and phenolic acids in the NESTE extract produced from fermentation process using Rhizopus 5351 strain have significant anti-inflammatory and analgesic effects without causing acute toxicity in mice. Nevertheless, further studies are needed to assess the detailed mechanisms of individually isolated active ingredients in NESTE that contributed to these activities.

\section{Abbreviations}

DMEM: Dulbecco's modified eagle medium; DMSO: Dimethyl sulfoxide; DPPH: 2,2-diphenyl-1-picrylhydrazyl; FBS: Foetal bovine serum; FRAP: Ferric reducing ability power; GABA: Gamma-aminobutyric acid;

LPS: Lipopolysaccharide; MARDI: Malaysian Agricultural Research and Development Institute; MTT: 3-(4,5-dimethylthiazol-2-yl)-2,5-

diphenyltetrazolium bromide; NESTE: Nutrient Enriched Soybean Tempeh;
NO: Nitric oxide; NSAIDs: Non-steroidal anti-inflammatory drugs; RNS: Reactive nitrogen species; ROS: Reactive oxygen species; S.E.M.: Standard error mean; SBE: Soybean aqueous extract; UPM: Universiti Putra Malaysia

\section{Acknowledgements \\ Not Applicable.}

\section{Authors' contributions}

SKY, KL, NBA designed the experiment; SPK and KL profiled and standardised the NESTE and SBE; HMY, NMA, SKY, WYH, BKB performed the experiment, HMY, NMA, SKY, WYH, BKB and SPK interpreted the results. HMY, SKY, NBA, $\mathrm{KL}$ prepared the manuscript. All authors have gone through and approved the manuscript. All authors have agreed both to be personally accountable for the author's own contributions and to ensure that questions related to the accuracy or integrity of any part of the work.

\section{Funding}

This project was funded by e-Science Fund (Ministry of Agriculture, Malaysia) grant no: 05-03-08 SF1057.The funder has no role/influence in this study.

\section{Availability of data and materials}

The datasets used and/or analyzed during the current study available from the corresponding author on reasonable request.

\section{Ethics approval}

The experiments were approved by Animal Care and Use Committee, Universiti Putra Malaysia (Ref: UPM/ FPV/ PS/ 3.2.1.551/AUP-R2) and was performed in accordance with the Guide for the Care and Use of Laboratory Animals prepared by the Institutional Animal Care and Use Committee (IACUC), UPM (Malaysia).

\section{Consent for publication \\ Not Applicable.}

\section{Competing interests}

Wan Yong $\mathrm{Ho}$ is the Associate Editor of BMC Complementary and Alternative Medicine. All authors in this article declare no conflict of interest.

\section{Author details}

${ }^{1}$ Department of Cell and Molecular Biology, Faculty of Biotechnology and Biomolecular Science, Universiti Putra Malaysia, 43400 Serdang, Selangor, Malaysia. ${ }^{2}$ China-ASEAN College of Marine Sciences, Xiamen University Malaysia, Jalan Sunsuria, Bandar Sunsuria, 43900 Sepang, Selangor, Malaysia. ${ }^{3}$ The University of Nottingham Malaysia Campus, Jalan Broga, 43500 Semenyih, Selangor, Malaysia. ${ }^{4}$ Institute of Bioscience, Universiti Putra Malaysia, Serdang, Selangor, Malaysia. ${ }^{5}$ Biotechnology Research Centre, Malaysian Agricultural Research and Development Institute (MARDI), 43400 Serdang, Selangor, Malaysia.

Received: 11 April 2019 Accepted: 8 December 2019 Published online: 19 December 2019

\section{References}

1. Selvi VS, Bhaskar A. Characterization of anti-inflammatory activities and antinociceptive effects of papaverine from Sauropus androgynus (L.) Merr. Glob J Pharmacol. 2012;6:186-92.

2. Bitra MJ, Fulmali S, Kataria M, Shraddha A, Harsha K. Anti-inflammatory activity of the fruits of Piper longum Linn. Asian J Chem. 2008:20:4357-62.

3. Szliszka E, Skaba D, Czuba ZP, Krol W. Inhibition of inflammatory mediators by neobavaisoflavone in activated RAW264.7 macrophages. Molecules. 2011; 16:3701-12.

4. Kim AR, Cho JY, Zou Y, Choi JS, Chung HY. Flavonoids differentially modulate nitric oxide production pathways in lipopolysaccharide-activated RAW264.7 cells. Arch Pharm Res. 2005;28:297-304.

5. Yoon SB, Lee YJ, Park SK, Kim HC, Bae H, Kim HM, Ko SG, Choi HY, Oh MS, Park W. Anti-inflammatory effects of Scutellaria baicalensis water extract on LPS-activated RAW 264.7 macrophages. J Ethnopharmacol. 2009;125:286-90.

6. Bjarnason I, Hayllar J, MacPherson A, Russell AS. Side effects of nonsteroidal anti-inflammatory drugs on the small and large intestine in humans. Gastroenterology. 1993;104:1832-47. 
7. Chandra S, Chatterjee P, Dey P, Bhattacharya S. Evaluation of antiinflammatory effect of Ashwagandha: a preliminary study in vitro. Phcog J. 2012:4:47-9.

8. Singh G, Triadafilopoulos G. Epidemiology of NSAID induced gastrointestinal complications. J Rheumatol. 1999;56:18-24.

9. Liu CF, Pan TM. Beneficial effects of bioactive peptides derived from soybean on human health and their production by genetic engineering, Soybean and Health. Prof. Hany El-Shemy (Ed.) 2011. ISBN: 978-953-307535-8, InTech, Available from: http://www.intechopen.com/books/soybeanandhealth/beneficial-effects-of-bioactivepeptides-derived-from-soybean-onhuman-health-and-their-production-b. Accessed 1 Oct 2017.

10. Yang HJ, Park S, Pak V, Chung KR, Kwon DY. Fermented soybean products and their bioactive compounds, Soybean and Health. Prof. Hany El-Shemy (Ed.), 2011. ISBN: 978-953-307-535-8, InTech, Available from: http://www. intechopen.com/books/soybean-and-health/fermentedsoybean- productsand-their-bioactive-compounds. Accessed 1 Oct 2017.

11. Liao CL, Huang H, Sheen L, Chou CC. Anti-inflammatory activity of soymilk and fermented soymilk prepared with lactic acid bacterium and bifidobacterium. J Food Drug Anal. 2010;18:202-10.

12. Haron H, Ismail A, Shahar S, Azlan A, Peng LS. Apparent bioavailability of isoflavones in urinary excretions of postmenopausal Malay women consuming tempeh compared with milk. Int J Food Sci Nutr. 2011;62:642-50.

13. Nout MJR, Kiers JL. Tempe fermentation, innovation and functionality: update into the third millennium. J Appl Microbiol. 2005;98:789-805.

14. Ali NM, Yeap SK, Yusof HM, Beh BK, Ho WY, Koh SP, Abdullah MP, Alitheen NB, Long K. Comparison of free amino acids, antioxidants, soluble phenolic acids, cytotoxicity and immunomodulation of fermented mung bean and soybean. J Sci Food Agric. 2016;96:1648-58.

15. Mosmann T. Rapid colorimetric assay for cellular growth and survival: application to proliferation and cytotoxicity assays. J Immunol Methods. 1983;65:55-63.

16. Huang WC, Lin YS, Wang CY, Tsai CC, Tseng HC, Chen CL, Lu PJ, Chen PS, Qian L, Hong JS, Lin CF. Glycogen synthase kinase-3 negatively regulates anti-inflammatory interleukin-10 for lipopolysaccharide-induced iNOS/NO biosynthesis and RANTES production in microglial cells. Immunology. 2009; 128:e275-86.

17. OECD. Test Guideline for Testing of Chemicals, Section 4, No. 423. Acute oral toxicity acute toxic class method. Organization for Economic Cooperation and Development Section 4, 2001;no. 423.

18. Luna LG. Manual of histologic staining methods of the armed forces Institute of Pathology, vol. 121. New York: McGraw-Hill; 1968.

19. Tapondjou LA, Lontsi D, Sondengam BL, Choi J, Lee KT, Jung HJ, Park HJ. In vivo anti-nociceptive and anti-inflammatory effect of the two triterpenes, ursolic acid and 23-hydroxyursolic acid, from Cussonia bancoensis. Arch Pharm Res. 2003;26:143-6.

20. He H, Li W, Chen SY, Zhang S, Chen YT, Hayashida Y, Zhu YT, Tseng SC. Suppression of activation and induction of apoptosis in RAW264.7 cells by amniotic membrane extract. Invest Ophthalmol Vis Sci. 2008;49:4468-75.

21. Kole L, Giri B, Manna SK, Pai B, Ghosh S. Biochanin-a, an isoflavon, showed anti-proliferative and anti-inflammatory activities through the inhibition of iNOS expression, p38-MAPK and ATF-2 phosphorylation and blocking NFKB nuclear translocation. Eur J Pharmacol. 2011;653:8-15.

22. Wu CH, Chen TL, Chen TG, Ho WP, Chiu WT, Chen RM. Nitric oxide modulates pro- and anti-inflammatory cytokines in lipopolysaccharideactivated macrophages. J Trauma. 2003;55:540-5.

23. Yusof HM, Ali NM, Yeap SK, Ho WY, Beh BK, Koh SP, Long K, Aziz SA, Alitheen NB. Hepatoprotective effect of fermented soybean (nutrient enriched soybean tempeh) against alcohol-induced liver damage in mice. Evid Based Complement Alternat Med. 2013:2013:274274.

24. Nout MJR. Fermented foods and food safety. Food Res Int. 1994;27:291-8.

25. Nair $A B$, Jacob S. A simple practice guide for dose conversion between animals and human. J Basic Clin Pharm. 2016;7:27-31.

26. Nakajima N, Nozaki N, Ishihara K, Ishikawa A, Tsuji H. Analysis of isoflavone content in tempeh, a fermented soybean, and preparation of a new isolavone-enriched tempeh. J Biosci Bioeng. 2005;100:685-7.

27. Zhu S, Li W, Li J, Jundoria A, Sama AE, Wang H. It is not just folklore: the aqueous extract of mung bean coat is protective against sepsis. Evid Based Complement Alternat Med. 2012;2012:498467.

28. Prud'homme G, Glinka Y, Wang Q. GABA exerts anti-inflammatory and immunosuppressive effects (P5175). J Immunol. 2013;190(Meeting Abstracts 1):68.15.
29. Hasegawa S, Ichiyama T, Sonaka I, Ohsaki A, Okada S, Wakiguchi H, Kudo K, Kittaka S, Hara M, Furukawa S. Cysteine, histidine and glycine exhibit antiinflammatory effects in human coronary arterial endothelial cells. Clin Exp Immunol. 2012;167(2):269-74.

30. Choi J, Kwon SH, Park KY, Yu BP, Kim ND, Jung JH, Chung HY. The antiinflammatory action of fermented soybean products in kidney of high-fatfed rats. J Med Food. 2011;14(3):232-9.

31. Lee JY, Jang YW, Kang HS, Moon H, Sim SS, Kim CJ. Anti-inflammatory action of phenolic compounds from Gastrodia elata root. Arch Pharm Res. 2006;29(10):849-58.

32. Mirza NR, Munro G. The role of GABA(a) receptor subtypes as analgesic targets. Drug News Perspect. 2010;23(6):351-60.

33. Ninomiya $Y$, Kawamura H, Nomura $T$, Uebayashi H, Sabashi K, Funakoshi M. Analgesic effects of D-amino acids in four inbred strains of mice. Comp Biochem Physiol C. 1990:97(2):341-3.

34. Mothana RA, Al-Said MS, Al-Rehaily AJ, Thabet TM, Awad NA, Lalk M, Lindequist U. Anti-inflammatory, antinociceptive, antipyretic and antioxidant activities and phenolic constituents from Loranthus regularis Steud. Ex Sprague. Food Chem. 2012;130(2):344-9.

\section{Publisher's Note}

Springer Nature remains neutral with regard to jurisdictional claims in published maps and institutional affiliations.
Ready to submit your research? Choose BMC and benefit from:

- fast, convenient online submission

- thorough peer review by experienced researchers in your field

- rapid publication on acceptance

- support for research data, including large and complex data types

- gold Open Access which fosters wider collaboration and increased citations

- maximum visibility for your research: over 100M website views per year

At BMC, research is always in progress.

Learn more biomedcentral.com/submissions 